\title{
The developing ovary of the South American plains vizcacha, Lagostomus maximus (Mammalia, Rodentia): massive proliferation with no sign of apoptosis-mediated germ cell attrition
}

\author{
N P Leopardo, F Jensen, M A Willis, M B Espinosa and A D Vitullo \\ Centro de Estudios Biomédicos, Biotecnológicos, Ambientales y Diagnóstico, CEBBAD, Universidad Maimónides, \\ Hidalgo 775, C1405BCK Buenos Aires, Argentina
}

Correspondence should be addressed to A D Vitullo; Email: vitullo.alfredo@maimonides.edu

N P Leopardo and F Jensen contributed equally to this work

F Jensen is now at Experimental Obstetrics and Gynaecology, Medical Faculty, Otto-von-Guericke University, Magdeburg, Germany

\begin{abstract}
Apoptosis-dependent massive germ cell death is considered a constitutive trait of the developing mammalian ovary that eliminates $65-85 \%$ of the germinal tissue depending on the species. After birth and during adult lifetime, apoptotic activity moves from the germ cell proper to the somatic compartment, decimating germ cells through follicular atresia until the oocyte reserve is exhausted. In contrast, the South American rodent Lagostomus maximus shows suppressed apoptosis-dependent follicular atresia in the adult ovary, with continuous folliculogenesis and massive polyovulation, which finally exhausts the oocyte pool. The absence of follicular atresia in adult $L$. maximus might arise from a failure to move apoptosis from the germinal stratum to the somatic compartment after birth or being a constitutive trait of the ovarian tissue with no massive germ cell degeneration in the developing ovary. We tested these possibilities by analysing oogenesis, expression of germ cell-specific VASA protein, apoptotic proteins BCL2 and BAX, and DNA fragmentation by TUNEL assay in the developing ovary of $L$. maximus. Immunolabelling for VASA revealed a massive and widespread colonisation of the ovary and proliferation of germ cells organised in nests that disappeared at late development when folliculogenesis began. No sign of germ cell attrition was found at any time point. BCL2 remained positive throughout oogenesis, whereas BAX was slightly detected in early development. TUNEL assay was conspicuously negative throughout the development. These results advocate for an unrestricted proliferation of germ cells, without apoptosis-driven elimination, as a constitutive trait of $L$. maximus ovary as opposed to what is normally found in the developing mammalian ovary.

Reproduction (2011) 141 633-641
\end{abstract}

\section{Introduction}

Development of the mammalian female germ line begins with the migration of the primordial germ cells (PGCs) from the base of the allantoids to the genital ridge (Lawson et al. 1999, McLaren 1999, Matova \& Cooley 2001). During migration, and after the colonisation of the primordial gonads, the PGCs proliferate and differentiate giving rise to a large number of oogonia. Mitotic proliferation is followed by the entrance of germ cells in the prophase of the first meiotic division to produce a pool of oocytes arrested at the diplotene stage of prophase I (Rucker et al. 2000, De Felici et al. 2005). As long as germ cells proceed through prophase I, they enter in close contact with somatic cells that surround the oocytes to form primordial follicles initiating the folliculogenesis (Baker \& Franchi 1967). Depending on the species, development through mitotic proliferation, meiosis entrance and folliculogenesis may occur sequentially or as overlapping processes during gestation (Kurilo 1981). In any case, an extensive constitutive degeneration of germ cells affecting proliferating PGCs, oogonia, and mainly the oocytes at the zygotene and pachytene stages of prophase I, decimates the germinal reserve (Baker 1963, Baker \& Franchi 1967). It has widely been accepted that massive constitutive elimination is a general feature of the dynamics of mammalian female germ cell development whose significance may be an extreme control selection process to preserve good 
quality oocytes and maximise the chances of reproductive success (Tilly 2001). Programmed cell death (PCD) or apoptosis is responsible for the loss of germ cells in the developing mammalian ovary (Peters \& McNatty 1980, Hsueh et al. 1996, Tilly 1996a, 1996b, De Felici 1999, De Felici et al. 2005), and genes belonging to the BCL2 family play an essential role in germ line development and establishment (Tilly et al. 1997, Tilly 2001). Studies mainly performed in mice, rats and humans have shown that ovarian germinal tissue displays an enhanced expression of apoptosis-inducing $B A X$ and low levels of apoptosis-inhibiting $B C L 2$, which are responsible for the high rate of apoptosis that characterises the developing mammalian ovary (Kim \& Tilly 2004, Albamonte et al. 2005, 2008, Hussein 2005). Apoptotic activity in the developing ovary is restricted to the germ cell proper, both PGCs, oogonia and oocytes, rather than to pregranulosa/granulosa cells, a process referred to as germ cell attrition. After birth, once the primordialfollicle enclosed oocyte pool has been established, apoptotic activity moves to the somatic compartment involving primarily the granulosa cells of resting follicles (Vaskivuo et al. 2001), and oocyte loss continues throughout reproductive lifetime as the result of follicular atresia.

The South American plains vizcacha, Lagostomus maximus, is a fossorial rodent belonging to the suborder hystricognatha, distributed in the Southern region of the Neotropics. This is a seasonal breeder, medium-sized caviomorph with a $4 \mathrm{~kg}$ body mass in adult females and $6.3 \mathrm{~kg}$ in males (Jackson et al. 1996). Gestation lasts around 154 days (Weir 1971a), a very unusually long period for a rodent and one of the longest recorded in hystricomorphs. In addition, L. maximus shows the highest ovulation rate described for a mammal, releasing between 400 and 800 oocytes at each oestrous cycle (Weir 1970, 1971a, 1971b). However, it seems that just a few (10 to 12) oocytes are fertilised and only one to two embryos are gestated to term (Weir et al. 1971b). Massive polyovulation in L. maximus has classically been explained as the result of a highly convoluted ovary that increases the organ surface for ovulation and the lack of detectable follicular atresia by standard staining (Weir 1971b, Mossman \& Duke 1973). More recently, we have shown that the apoptosis-inhibiting BCL2 gene is highly overexpressed from primordial to fully mature antral follicles in the adult ovary of L. maximus, while apoptosis-inducing $B A X$ gene shows low levels of expression or is not detected, leading to a strong suppression of apoptosis-dependent follicular atresia. Suppression of apoptosis-dependent follicular atresia in L. maximus opposes to what is commonly found in other mammals, and it seems to relate directly to the massive ovulatory phenotype and the maintenance of pregnancy to term (Jensen et al. 2008). The absence of follicular atresia in the mature ovary of the plains vizcacha could be attributed to a failure in moving apoptosis from germ cells to the somatic compartment after birth (described earlier). If this is the case, it could be anticipated that the developing ovary should be subjected to considerable levels of germ cell attrition as it occurs in most mammalian species. Alternatively, if the absence of germ cell dismissal through apoptosis is a constitutive trait of the ovarian tissue in L.maximus, one could expect no massive germ cell degeneration in the developing ovary leading to an overpopulated germ line at birth. In such a case, massive ovulation might act as the alternative mechanism of oocyte loss in this species.

In order to discern between these two possibilities, we have investigated the dynamics of germ cell formation in the developing ovary of L. maximus, through the analysis of the distribution of the specific germ cell marker VASA to evaluate colonisation and proliferation in the foetal gonad, through the evaluation of apoptotic germ cell activity by a DNA in situ labelling assay, and through the expression balance of $B C L 2$ and $B A X$ genes from early to late development in order to encompass the transition from oogonial mitotic proliferation to the entrance to meiosis, the course of prophase I, and the primordial follicle formation.

\section{Results}

\section{General morphology and histology of the foetal ovary in L. maximus}

Foetal ovary in L. maximus showed a typical oval shaped, compact and solid morphology, with no sign of invagination of the surface epithelium deep into the organ as described in the adult ovary. Early developing ovaries were abundantly packed with germ cells, mainly oogonia at interphase or undergoing mitosis (Fig. 1). Although oogonia were distributed in the entire ovary among somatic cells, two different regions were clearly distinguished according to germ cell density and organisation. The cortical external area was very rich in germ cells with oogonia organised in ovarian cords (Fig. 1B) with a low proportion of somatic cells, whereas in the internal region somatic cells prevailed in the face of germ cells (Fig. 1A). Oogonia in mitosis (Fig. 1C) and oocytes in the early stages of meiosis organised in small nests of two-eight cells, which often displayed a similar stage of cell cycle. Mid developing ovary showed a considerable proportion of primary oocytes that had entered early stages of prophase I (Fig. 1D), distributed mainly in the internal region often close to the area connected to the mesonephros by the rete ovarii. Proliferating oogonia remained in the cortical external area. At late development, oocytes were still organised in nests (Fig. 1E), and the ovary was plentiful of incipient primordial follicles with oocytes in different meiotic stages (Fig. 1F). Isolated oogonia/oocytes still remained at the external cortical region. 

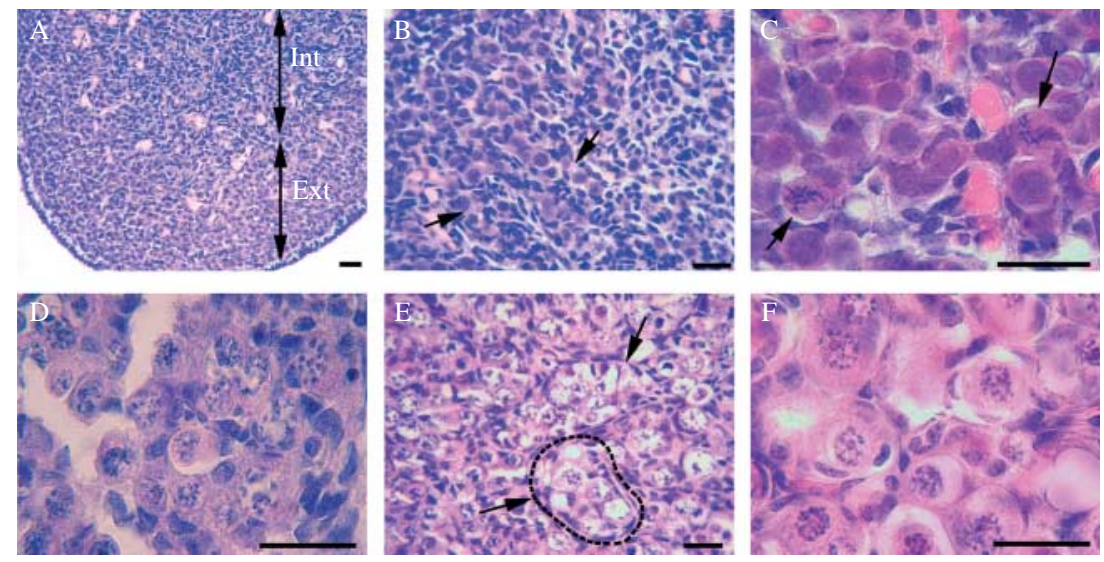

Figure 1 General histology of the developing ovary in L. maximus. (A) Panoramic view of an early developing ovary abundantly packed with oogonia distributed in the entire organ. Note the difference in germ cell density between the external (ext) and internal (int) areas. (B) Detail of the cortical external area at early development showing oogonia organised in cords (arrow) surrounded by somatic cells. (C) Detail of germ cells organised in a nest; note the presence of proliferating oogonia (arrows). (D) Mid developing ovary showing primary oocytes that have entered prophase I. (E) Nest-organised distribution (arrows) of oocytes at mid development; the dotted area indicates one nest. (F) Characteristic view of the late developing ovary plentiful of incipient primordial follicles. Bar $=20 \mu \mathrm{m}$.

\section{Germ cell distribution and progression through oogenesis: VASA expression}

Cytoplasmic VASA immunolabelling was detected in oogonia, primary oocytes and primordial follicle-enclosed oocytes, at all developmental ages analysed (Fig. 2). In early developing ovary, VASA showed a bright, punctuated distribution in oogonia that clearly highlighted the organisation of germ cells in nests with no clear-cut among cells, revealing cytoplasmic interconnection (Fig. 2A and B). Signal intensity was still bright and punctuated in mid developing ovaries with a clear-cut limit among germ cells (Fig. 2C and D). Germ cell nests or cysts could be still observed clearly delimited by somatic cells that had also invaded the nest (Fig. 2C and D). A closer inspection of nests showed the coexistence of interconnected oogonia distributed in the periphery of the nest and well-defined primary oocytes dispersed among somatic cells in the internal area (Fig. 2D). Late developing ovaries showed a more homogeneous VASA distribution covering the entire cytoplasm of oocytes, which had entered in close contact with somatic cells in incipient primordial follicles (Fig. 2E and F). In all gestational ages analysed, ovarian sections incubated in the absence of primary antibodies did not exhibit detectable immunolabelling (Fig. 3G). Widespread expression of VASA throughout ovarian development was confirmed by conspicuous detection in western blot (Fig. 2H).

\section{Immunohistochemical localisation and expression of BCL2 and BAX proteins}

Immunodetection of BCL2 protein was positive in early, mid, and late developing ovaries. At early development, BCL2 positive immunostaining was particularly strong, displayed a decreased intensity in mid developing ovaries and became stronger again in late developing ovaries (Fig. $3 \mathrm{~A}-\mathrm{C}$ ). It is interesting to note that the decrease in immunostaining intensity for BCL2 was coincident with the entrance in meiosis. The pattern of BAX immunodetection was quite different from that of BCL2 and displayed a time-restricted expression.
Positive slight immunostaining was just detected in early developing ovary (Fig. 3D) and became negative, except for occasional isolated germ cells, in mid and late developing ovaries (Fig. 3E and F). The same pattern of strong immunostaining for BCL2 and slight or negative staining for BAX was reproducible in all samples analysed from different embryos. Western blot analysis was consistent with immunohistochemical (IHC) observations. Enhanced amounts of immune-reactive protein corresponding to BCL2 (26 kDa) were found in early, mid and late gestating ovaries (Fig. 4A) compared with those in the control tissues. In agreement with IHC observations, a slight decrease in BCL2 detection was evident in mid developing ovary (Fig. 4B). In contrast, BAX significantly decreased from early to late development (Fig. 4B).

\section{Apoptosis in the developing ovary of L. maximus: TUNEL assay}

Apoptosis studied by TUNEL technique showed to be conspicuously negative in sections belonging to early, mid, and late developing ovaries (Fig. 5A, C, and E). Occasionally, a few isolated germ cells were found to be positive (Fig. 5B, D, and F) in all developmental time points. In order to confirm negative TUNEL results, treated sections were incubated with DNase and reprocessed by TUNEL protocol. After this treatment, all nuclei become positive, confirming that DNA was originally not fragmented in the samples (Fig. 5G).

\section{Discussion}

In contrast to what is normally found in studied mammalian species, the results presented in this study indicate that the establishment of the female germ line in L. maximus takes place in the absence of germ cell attrition, representing the first description of abolished massive germ cell elimination in the developing mammalian ovary. Over expression of apoptosisinhibiting $B C L 2$ gene together with the absence of 

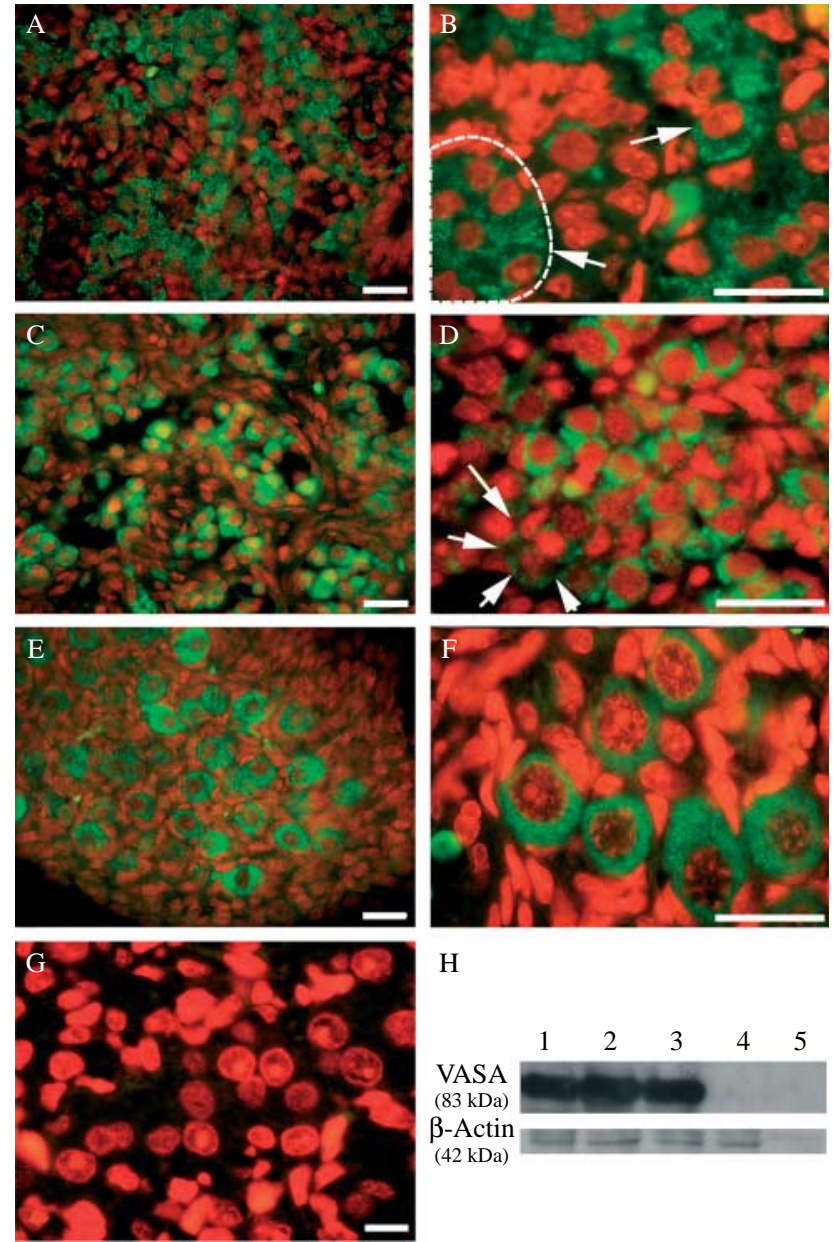

$\mathrm{H}$

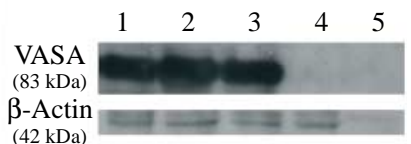

Figure 2 Immunodetection of the specific germ cell marker VASA (green staining) in developing ovary of L. maximus. (A) Oogonia in early developing ovary displaying bright and punctuated VASA immunolabelling with no clear-cut distribution among cells. (B) Detail of nest-organised germ cells (arrows) showing no cell limits in VASA signal (dotted area). (C) Brighter and still punctuated distribution of VASA immunolabelling in germ cells in mid developing ovary organised in nests. Note that VASA signal became mostly cellcontained. (D) Detail of a germ cell nest showing cell-contained VASA signal in the centre of the nest and still interconnected oogonia in the nest periphery (arrows). (E) Panoramic view of homogeneously distributed VASA immunolabelling in the entire cytoplasm of oocytes at late development. (F) Detail view of VASA signal in diplotene-arrested oocytes in incipient primordial follicles at late development.

(G) Negative control in early developing ovary. $(\mathrm{H})$ Expression in western blotting for early (lane 1), mid (lane 2) and late developing ovary (lane 3) protein extracts and control homospecific tissues, spleen (lane 4) and muscle (lane 5). Bar $=20 \mu \mathrm{m}$. Red staining: nuclear DNA counterstained with propidium iodide.

apoptosis-inducing $B A X$ gene expression and the low level of apoptotic germ cell nuclei detected by TUNEL assay support the idea that abolished germ cell attrition in the developing ovary of $L$. maximus arises from a strong prevention of the intrinsic apoptosis pathway. A similar situation has been described in the adult ovary of $L$. maximus in which the BCL2 gene is overexpressed throughout folliculogenesis accompanied by a scarce detection of apoptosis-inducing BAX protein and a rare and occasional detection of TUNEL-positive follicles (Jensen et al. 2006). Prevention of germ cell demise in the foetal ovary and scarce follicular atresia in the adult indicate that the absence of germ cell dismissal through apoptosis is a constitutive trait of the ovarian tissue in L.maximus. Moreover, prevention of apoptosis through $B C L 2$ overexpression not only involves the germ cell proper and the supporting cells, granulosa and theca cells, but also extends to the corpora lutea preserving its structural integrity and functionality during the whole gestation (Jensen et al. 2008), reinforcing the hypothesis that the BCL2 gene family shows an ovary-specific regulation in order to maintain low levels of apoptosis-dependent germ cell elimination in this mammalian species.

Apoptosis-dependent massive germ cell death has been regarded as a constitutive trait of the developing mammalian ovary that eliminates $65-85 \%$ of the germinal tissue depending on the species (Flaws et al. 2001, Guigon \& Magre 2006). Much of our understanding of this process has emerged from studies performed in mice, rats and humans, and to a lesser extent in other mammals. Although multiple genes are known to regulate apoptosis, $B A X$ and $B C L 2$ genes play an essential role in the mammalian ovary since they function as a rheostat determining cell death or survival through the expression balance between the proteins they encode (Tilly et al. 1997, Tilly 2001). In fact, proapoptotic $B A X$ seems to be up-regulated by default in the mammalian ovary, being responsible for massive germ cell degeneration by attrition of foetal germ cells and apoptosis-dependent follicular atresia in the adult (Kim \& Tilly 2004, Albamonte et al. 2008). The central role of the $B C L 2 / B A X$ balance in prevention of apoptosis has been supported through experimental BCL2 transfection of cell lines that protect cultured cells from death (Reed 1994). Moreover, BCl2- and Bax-deficient knockout mice have decreased or increased primordial follicles respectively (Knudson et al. 1995, Ratts et al. 1995). Our results indicate that $B C L 2 / B A X$ are expressed in the developing ovary of $L$. maximus in the opposite way from that found in mice (Kim \& Tilly 2004), rats (Tilly et al. 1995), monkeys (Uma et al. 2003), quail (Van Nassaw et al. 1999) and humans (Vaskivuo et al. 2001, Albamonte et al. 2008), with a biased expression in favour of the apoptosis-inhibiting BCL2 protein and a time-restricted or absent expression of BAX. This seems to preserve the germinal reserve from apoptosis with little or no restriction to proliferation, a situation that reminds the pattern of enhanced BCL2 expression contributing to uncontrolled proliferation and cell survival in many cancers (Kirkin et al. 2004). The very low levels of apoptosis revealed by TUNEL assay indicate a strong prevention of germ cell attrition and little or no restriction to proliferation. However, it 

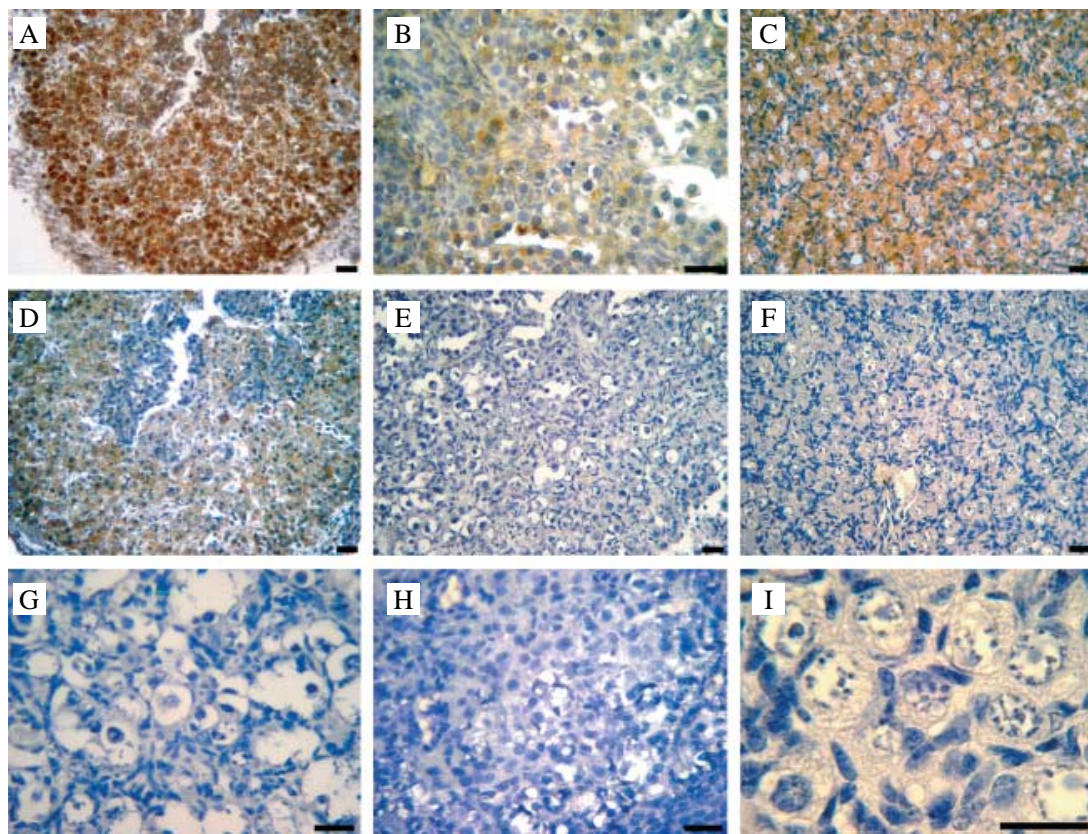

Figure 3 BCL2 and BAX protein immunohistochemical detection in the developing ovary of L. maximus. (A) Apoptosis-inhibiting BCL2 protein showed a strong immunolabelling at early development, (B) decrease in intensity in mid developing ovary and $(\mathrm{C})$ becoming stronger again by late development. (D) Apoptosisinducing BAX was slightly detected in earlydeveloping ovary and (E) became undetectable at mid and (F) late development. (G-I)

Representative negative control performed by omitting the primary antibody. Bar $=20 \mu \mathrm{m}$. is worthwhile to consider that other mechanisms may be acting in the developing ovary of L. maximus. For instance, it has been shown that germ cell exfoliation from the ovarian surface contributes to eliminate PGCs, oogonia and oocytes in the developing human ovary (Motta et al. 1997).

General histology and the pattern of VASA expression that we found in the developing ovary of $L$. maximus are commensurate with a high level of colonisation through proliferation. Although just three time-points have qualitatively been analysed through the 5-month-long gestation of the plains vizcacha, it is worth to note that the genesis of the germ line proceeds through the overlapping of the main processes involved in the gonadal development: mitotic proliferation, entrance to meiotic prophase I and germ cell-somatic cell association to form primordial follicles. All those essential changes that occur in ovarian organogenesis were reflected by the stage-specific immunodetection pattern displayed by VASA protein. In the early developing ovary, VASA showed a widespread distribution in proliferative germ cell nests reflecting the interconnection of cells. Once germ cells entered meiosis and folliculogenesis in mid and late development, VASA displays a cell-restricted immunostaining pattern. In all cases, however, immunoreaction extended to the entire cytoplasm. In mice and humans, once the oocytes enter prophase I and folliculogenesis, VASA protein displays a restricted aggregation in a cytoplasmic paranuclear localisation corresponding to the Balbiani's vitelline space (Balbiani 1864), a cytoplasmic complex composed of mitochondria, endoplasmic reticulum and lamellar aggregates (Hertig \& Adams 1967, Pepling et al. 2007). In the developing human ovary that displays the highest germ cell elimination reaching $85 \%$ of the germinal reserve before birth (Baker 1963, Forabosco et al. 1991), most of the primordial follicle-enclosed oocytes show VASA protein associated to Balbiani's body (Castrillon et al. 2000), and it has been estimated that only around $10 \%$ of the oocytes display
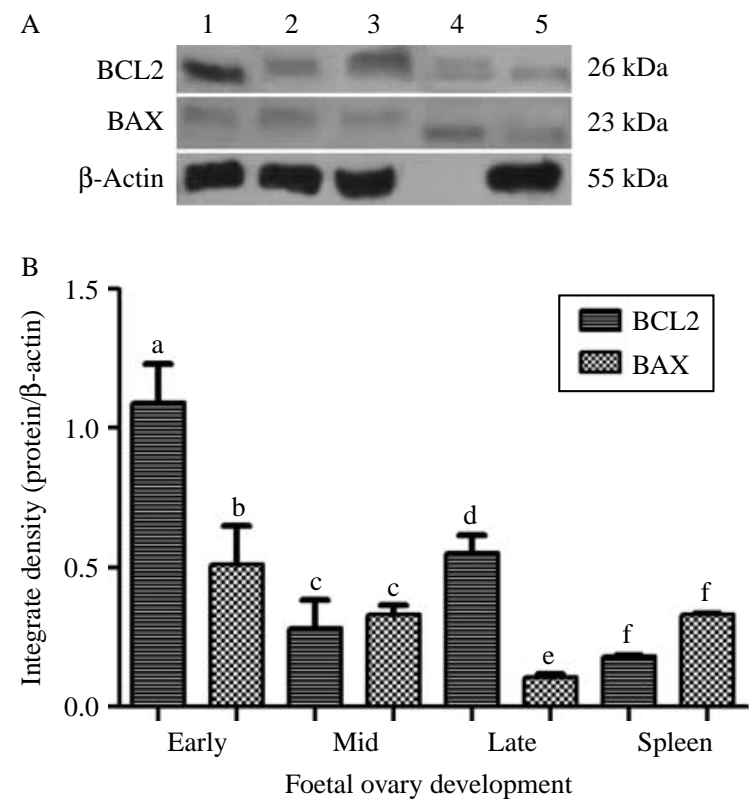

Figure 4 Western blot analysis for BCL2 and BAX proteins in the developing ovary of L. maximus. (A) Early (lane 1), mid (lane 2 ) and late developing ovary (lane 3), and control homospecific tissues, muscle (lane 4) and spleen (lane 5). (B) Integrate density calculated against control load (actin) showing enhanced expression of BCL2 protein, especially at early and late development. Different letters above bars indicate significant differences between groups $(P<0.05)$. 

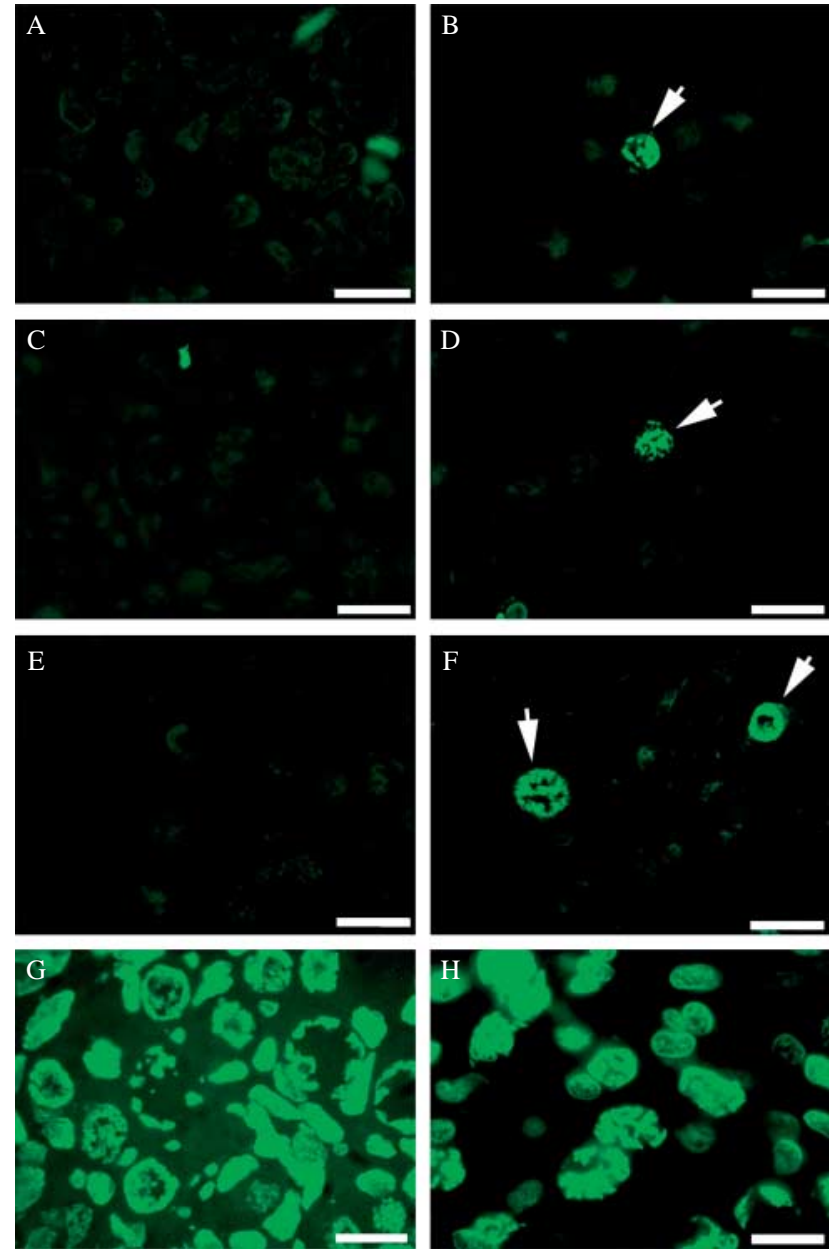

Figure 5 Apoptosis-related DNA fragmentation detected by TUNEL assay in the developing ovary of $L$. maximus. Ovaries were conspicuously negative during early (A), mid (C) and late development (E). A closer inspection at a higher magnification revealed rare and isolated TUNEL-positive germ cell nuclei for early (B), mid (D) and late developing ovaries (F). (G) Negative TUNEL sections treated with DNase and re-processed by TUNEL protocol confirmed true negative results, since all nuclei became positive indicating intact DNA prior to enzyme digestion. (H) Positive control (see Materials and Methods). Bar $=20 \mu \mathrm{m}$.

a widespread cytoplasmic distribution of VASA (Albamonte et al. 2008). We did not detect VASA aggregated to the Balbiani's space in any sample analysed in the developing ovary of the plains vizcacha. It is worth to note that developing ovaries of human and Lagostomus show an opposite behavior, the former having almost $85 \%$ of germ cell dismissal by birth, the latter having abolished apoptosis and germ cell elimination throughout foetal development as shown in this study. Considering that VASA is a DEAD box, RNAbinding protein involved in the assembly and transport of mRNAs during oogenesis (Castrillon et al. 2000) and Balbiani's body is viewed as a structure related to universal mechanisms of RNA metabolism (Pepling et al. 2007), it is tempting to propose that the association or not of VASA protein to the Balbiani's space may relate to the final fate of the oocyte, death or survival, in the light of the differences found between humans and L. maximus.

In conclusion, we have shown that germ cells may not be necessarily committed to death through massive apoptosis as a constitutive feature of the developing mammalian ovary. Unrestricted proliferation of germ cells, without apoptosis-driven elimination, in the developing ovary of $L$. maximus reveals the existence of alternative strategies for oocyte production in mammals and bolsters our contention that mechanisms shared by a few species not necessarily apply to all mammals.

\section{Materials and Methods}

\section{Animals}

The experimental protocol described in this study was reviewed and authorised by the Ethics and Research Committee of Universidad Maimónides, Argentina. Handling and killing of captured animals were performed in accordance with the standards defined in the guide for the care and use of laboratory animals (CCAC 2002), and guidelines on the care and use of wildlife (CCAC 2003) from the Canadian council of animal care. Plain vizcachas, $L$. maximus, were captured from a natural population at the Estación de Cría de Animales Silvestres (ECAS), Ministry of Agriculture, Villa Elisa, Buenos Aires province, Argentina, at three different time points during the main breeding season (from March-April to AugustSeptember), in order to obtain early, mid and late gestating embryos during the 5.5-month length gestation period. A total of 13 samples classified as early $(N=6)$, mid $(N=4)$ and late gestating $(N=3)$ embryos were collected from ten pregnant females. Female gestational age was estimated on the basis of capture time, examination of foetal morphology, foetal weight and crown-heel length.

\section{Tissue collection and processing}

Gestating females were intraperitoneally anesthetised with ketamine $(10 \mathrm{mg} / \mathrm{kg}$ body weight; ketamine clorhydrate, Holliday Scott S.A., Buenos Aires, Argentina) and xilacine $(1 \mathrm{mg} / \mathrm{kg}$ of body weight; xilacine clorhydrate, Laboratorios Richmond, Buenos Aires, Argentina), and immediately killed by trained technical staff by an intracardiac injection of Euthanyle

Table 1 Foetus growth and foetal ovary size in Lagostomus maximus throughout development.

\begin{tabular}{lcccccc}
\hline & & \multicolumn{2}{c}{ Foetus } & & \multicolumn{2}{c}{ Foetal ovary } \\
\cline { 3 - 4 } $\begin{array}{l}\text { Gestation } \\
\text { (days) }\end{array}$ & $\mathbf{N}$ & $\begin{array}{c}\text { Length } \\
(\mathrm{mm})\end{array}$ & $\begin{array}{c}\text { Weight } \\
(\mathrm{g})\end{array}$ & & $\begin{array}{c}\text { Length } \\
(\mathrm{mm})\end{array}$ & $\begin{array}{c}\text { Width } \\
(\mathrm{mm})\end{array}$ \\
\hline Early $(50 \pm 15)$ & 6 & $30.4 \pm 5.3$ & $3.1 \pm 1.2$ & & $1.3 \pm 0.4$ & $\mathrm{NR}$ \\
Mid $(90 \pm 15)$ & 4 & $87.0 \pm 7.0$ & $52.0 \pm 16.0$ & & $4.5 \pm 1.4$ & $2.6 \pm 0.7$ \\
Late $(140 \pm 15)$ & 3 & $185.0 \pm 1.5$ & $90.0 \pm 10.0$ & $7.9 \pm 1.2$ & $4.5 \pm 0.6$
\end{tabular}

$\mathrm{NR}$, not registered. Data are expressed as mean \pm S.E.M. 
$(0.2 \mathrm{ml} / \mathrm{kg}$ of body weight; sodium pentobarbital, sodium diphenyl hydantoinate; Brouwer S.A., Buenos Aires, Argentina). Uterine horns were exposed, and embryos were removed, weighed and measured (Table 1). Left and right ovaries were dissected out from the embryos under a stereomicroscope, and width and length were immediately recorded (Table 1). For histochemical analysis, one ovary was fixed in cold $4 \%$ neutral-buffered paraformaldehyde (PFA) for $24 \mathrm{~h}$, and the other one was frozen at $-80{ }^{\circ} \mathrm{C}$ until used for protein isolation. When more than one foetus was implanted in the same uterine horn (especially at early and mid gestation stage) only the distal foetuses were used for further analyses since it is known that only the embryos nearest to the cervix develop normally to term (Weir 1971a, 1971b, Jensen et al. 2008). PFA-fixed tissues were dehydrated through a graded series of ethanol and embedded in paraffin, and the whole sample was serially sectioned at $5 \mu \mathrm{m}$ and mounted onto cleaned coated slides. For each specimen, at least three to five slides were stained with haematoxylin-eosin for general histological inspection. The remaining serial-sectioned slides to those used for haematoxylin-eosin staining were stored at room temperature until used for immunofluorescence, immunohistochemistry or TUNEL assay.

\section{Immunofluorescence analysis of VASA protein}

Mounted paraffin sections were dewaxed in xylene (Sigma Chemical Co.) and re-hydrated through a decreasing series of ethanol. After two 10 min rinses in PBS, they were incubated with a blocking solution containing $10 \%$ bovine foetal serum (BFS)/15\% BSA in PBS, pH7.4, for $1 \mathrm{~h}$ at room temperature. Then, the slides were thoroughly rinsed in PBS and incubated with polyclonal rabbit anti-Mvh (mouse Vasa homologue) primary antibody (1/500), kindly provided by $\mathrm{Dr}$ Noce (Mitsubishi Kagaku Institute of Life Sciences, Tokyo, Japan), overnight at $4{ }^{\circ} \mathrm{C}$. Although the primary antibody has been raised against mouse VASA protein, inmunodetection of L. maximus VASA protein can be anticipated since the high degree of conservation of this protein among different species (Lasko \& Ashburner 1988). Moreover, sequencing of L. maximus VASA homologue protein showed $90 \%$ homology with rat and mouse ( $\mathrm{F}$ Jensen, $\mathrm{ML}$ Muscarsel Isla, ML Bacigalupo, G Wöllmer \& AD Vitullo 2007, unpublished observations). After incubation with anti-Mvh, the slides were incubated with goat anti-rabbit IgG-FITC-conjugated antibodies (Santa Cruz Biotechnology, CA, USA) for $60 \mathrm{~min}$ at room temperature. All the slides were counterstained with $1 \mathrm{mg} /$ $\mathrm{ml}$ propidium iodide, washed for $30 \mathrm{~min}$ in PBS, and mounted with VectaShield mounting medium (Vector). Negative controls were performed by omitting the primary antibody. Samples were examined under an Olympus BX40 microscope by conventional epifluorescence with u.v. illumination, and images were captured with an Olympus Camedia C-5060 camera.

\section{IHC detection of BCL2/BAX}

Dewaxed and re-hydrated ovarian sections were subjected to blocking of endogenous peroxidase activity with $3 \% \mathrm{H}_{2} \mathrm{O}_{2}$ for $20 \mathrm{~min}$ at room temperature. They were then blocked with
$10 \% \mathrm{BFS} / 15 \% \mathrm{BSA}$ in $\mathrm{PBS} \mathrm{pH} 7.4$ for $1 \mathrm{~h}$ at room temperature and incubated overnight at $4{ }^{\circ} \mathrm{C}$ with specific rabbit polyclonal anti-BAX (1/500 Santa Cruz Biotechnology) or anti-BCL2 (1/500 Santa Cruz Biotechnology) antibodies. Antibodies employed were cross-reactive with mouse, rat and human proteins, and previously shown to recognise the targeted proteins in the vizcacha (Jensen et al 2006, 2008). Immunoenzymatic reactions were performed with $\mathrm{HRP}$ and revealed with $3^{\prime}, 3^{\prime}$-diaminobenzidine using the LSAB 2 System (DAKO Cytomation, Carpinteria, CA, USA). Procedure was as per the suppliers' recommendations. Staining for each antibody was repeated at least three times in separate assays for each specimen, using a minimum of two slides per assay. Sections assayed were entirely inspected under the microscope. Repetitions of assays performed in different days confirmed that staining was reproducible. Negative controls were performed by omitting the primary antibody or presorption with the synthetic peptides. All the slides were counterstained with haematoxylin.

\section{Western blot analysis}

Ovaries were immersed in five volumes of lysis buffer $(20 \mathrm{mM}$ Tris- $\mathrm{HCl}, \mathrm{pH} 8.0,137 \mathrm{mM} \mathrm{NaCl}, 1 \%$ Nonidet $\mathrm{P}-40$ and $10 \%$ glycerol) supplemented with protease inhibitors $(0.5 \mathrm{mM}$ PMSF, $0.025 \mathrm{mM} \mathrm{N-CBZ-L-phenylalanine} \mathrm{chloromethyl}$ ketone, $0.025 \mathrm{mM} \mathrm{N} \alpha$-p-tosyl-lysine chloromethyl ketone and $0.025 \mathrm{mM} \mathrm{L-1-tosylamide-2-phenyl-ethylchloromethyl}$ ketone). Then, samples were homogenised with a high-speed homogeniser, centrifuged at $10000 \mathrm{~g}$ for $10 \mathrm{~min}$ at $4{ }^{\circ} \mathrm{C}$, and pellets were discarded. Protein content of the supernatant was determined by the Bradford assay (Bio-Rad). Aliquots of proteins $(100 \mu \mathrm{g})$ were boiled for $5 \mathrm{~min}$, resolved by SDSPAGE $(15 \%)$ at $150 \mathrm{~V}, 1 \mathrm{~h}$ at $4{ }^{\circ} \mathrm{C}$, and transferred onto nitrocellulose membranes in transfer buffer containing $20 \%$ methanol (vol/vol), 0.19 M glycine and 0.025 M Tris-base $(\mathrm{pH}$ 8.3 ) at $250 \mathrm{~mA}$ during $70 \mathrm{~min}$ at $4{ }^{\circ} \mathrm{C}$. Molecular weight (MW) of corresponding proteins was determined in relation to $\mathrm{MW}$ Rainbow Markers (Amersham). Equal loading was confirmed by Ponceau $\mathrm{S}$ staining. After blocking unspecific binding with $\mathrm{PBS} / 5 \%$ skim milk overnight at $4{ }^{\circ} \mathrm{C}$, the nitrocellulose membranes were allowed to react with rabbit polyclonal antiBAX (1/1000, Santa Cruz Biotechnology), rabbit polyclonal anti-BCL2 (1/1000, Santa Cruz Biotechnology) or polyclonal rabbit anti-Mvh (VASA) as primary antibodies for $2 \mathrm{~h}$ at room temperature, followed by two extensive washes with $0.1 \%$ Tween 20 in PBS. Blotted proteins were detected by a polyclonal antibody HRP-conjugated (1:10 000) using the $\mathrm{ECL}$ western blot detection reagent (Amersham). Adult ovary and muscle protein extracts of $L$. maximus were employed as BCL2 and BAX controls (Jensen et al. 2006, 2008). Monoclonal antibody anti- $\beta$-actin was assayed to normalise the protein loading. Relative expression of BAX and BCL2 was quantified at each developmental time point by integrate density against the load control, with Scion Image Software (Scion Corporation, Frederick, MD, USA). Data are expressed as mean and S.E.M., plotted with GraphPad Prism Software, version 5 (San Diego, CA, USA) and statistically analysed by the Newman-Keuls test. Differences were considered significant when $P<0.05$. 


\section{TUNEL assay}

Detection of apoptosis-associated DNA fragmentation was performed in paraffin-embedded sections by TUNEL, using the 'In Situ Cell Death Detection Kit' (Roche Diagnostics) with fluorescein-tagged nucleotides. The procedure was done following the suppliers' recommendations. Treated sections were examined in an Olympus BX40 microscope by conventional epifluorescence with ultraviolet illumination. In order to confirm negative results, TUNEL-processed sections were incubated with $10 \mathrm{IU} / \mathrm{ml}$ DNasell (Sigma Chemical Co.) in $50 \mathrm{mM}$ Tris-HCL pH 7.5, $10 \mathrm{mM} \mathrm{Mg}_{2} \mathrm{Cl}$ and $1 \mathrm{mg} / \mathrm{ml}$ BSA for $10 \mathrm{~min}$ at room temperature. After incubation, the slides were thoroughly rinsed and treated again according to the TUNEL protocol. Negative control was done by omitting the deoxynucleotidyl transferase enzyme. A 20-week-old human foetal ovary section was included as a positive control at each TUNEL reaction. At this time-point, human ovary displays the highest TUNEL positivity throughout foetal development (Albamonte et al. 2008).

\section{IHC and immunofluorescence analyses}

In total, six sections were analysed at each IHC or immunofluorescence (IF) experiment for VASA, BCL2, BAX and TUNEL assays. The six sections were selected for every five consecutive cuts; thus, they were separated by a $30 \mu \mathrm{m}$ distance. If sections $1,6,12$, etc. were used for VASA, then sections 2, 7, 13, etc. were used for BCL2, and so on for BAX and TUNEL. This enabled us to have the three antibodies and TUNEL in a comparable $20 \mu \mathrm{m}$ matched area, in consecutive cuts. AII IHC, IF and TUNEL assays were repeated at least three times in separate and independent experiments. Treated samples were examined in an Olympus BX40 microscope attached to a photo camera Olympus Camedia C-5060 for image capture.

\section{Declaration of interest}

The authors declare that there is no conflict of interest that could be perceived as prejudicing the impartiality of the research reported.

\section{Funding}

This study was supported by a PICTO-CRUP (grant No. 30 972) from the Agencia Nacional de Promoción Científica y Técnica (ANPCyT) granted to ADV, and intramural funding from Universidad Maimónides.

\section{Acknowledgements}

We are especially grateful to the personnel of E C A S for their invaluable help in trapping and handling the animals and Ms Clara Ippólito for her technical assistance in tissue processing.

\section{References}

Albamonte MS, Elizondo K, Albamonte MI, Willis MA, Espinosa MB \& Vitullo AD 2005 Expresión de BCL-2/BAX y apoptosis en ovario humano adulto. Medicina 65 (Supplement II) 126.

Albamonte MS, Willis MA, Albamonte MI, Jensen F, Espinosa MB \& Vitullo AD 2008 The developing human ovary: immunohistochemical analysis of germ-cell specific VASA protein, BCL-2/BAX expression balance and apoptosis. Human Reproduction 23 1895-1901. (doi:10. 1093/humrep/den197)

Baker TG 1963 A quantitative and cytological study of germ cells in human ovaries. Proceedings of the Royal Society of London. Series B. Biological Sciences 158 417-433. (doi:10.1098/rspb.1963.0055)

Baker TG \& Franchi LL 1967 The fine structure of oogonia and oocytes in human ovaries. Journal of Cell Science 2 213-224.

Balbiani EG 1864 Sur la constitution du germe dans l'oeuf animal avant la fécondation. Comptes Rendus Hebdomadaires des Séances de l'Académie des Sciences 58 584-588.

Castrillon DH, Quade BJ, Wang TY, Quigley C \& Crum CP 2000 The human VASA gene is specifically expressed in the germ cell lineage. PNAS $\mathbf{9 7}$ 9585-9590. (doi:10.1073/pnas.160274797)

CCAC 2002 Guía para el cuidado y uso de animales de laboratorio, Mexican edition. Ottawa, ON, Canada: National Academy Press.

CCAC 2003 Guidelines on: The care and use of wildlife. Ottawa, ON, Canada: National Academy Press.

De Felici M $1999 \mathrm{Bcl}-2$ and Bax regulation of apoptosis in germ cell during prenatal oogenesis in the mouse embryo. Cell Death and Differentiation 6 908-915. (doi:10.1038/sj.cdd.4400561)

De Felici M, Klinger FG, Farini D, Scaldaferri ML, Iona S \& Lobascio M 2005 Establishment of oocyte population in the fetal ovary: primordial germ cell proliferation and oocyte programmed cell death. Reproductive BioMedicine Online 10 182-191. (doi:10.1016/S14726483(10)60939-X)

Flaws JA, Hirshfield AN, Hewitt JA, Babus JK \& Furth PA 2001 Effect of Bcl2 on the primordial follicle endowment in the mouse ovary. Biology of Reproduction 64 1153-1159. (doi:10.1095/biolreprod64.4.1153)

Forabosco A, Sforza C, De Pol A, Vizzotto L, Marzona L \& Ferrario VF 1991 Morphometric study of the human neonatal ovary. Anatomical Records 231 201-208. (doi:10.1002/ar.1092310208)

Guigon CJ \& Magre S 2006 Contribution of germ cells to differentiation and maturation of the ovary: insights from models of germ cell depletion. Biology of Reproduction $\mathbf{7 4}$ 450-458. (doi:10.1095/biolreprod.105. 047134)

Hertig AT \& Adams EC 1967 Studies on the human oocyte and its follicle. Ultrastructural and histochemical observations on the primordial follicle stage. Journal of Cell Biology 34 647-675. (doi:10.1083/jcb.34.2.647)

Hsueh AJW, Eisenhower K, Chun SY, Hsu SY \& Billig H 1996 Gonadal cell apoptosis. Recent Progress in Hormone Research 51 433-455.

Hussein MR 2005 Apoptosis in the ovary: molecular mechanisms. Human Reproduction Update 11 162-177. (doi:10.1093/humupd/dmi001)

Jackson JE, Branch LC \& Villarrreal D 1996 Lagostomus maximus. Mammalian Species 543 1-6. (doi:10.2307/3504168)

Jensen CF, Willis MA, Albamonte MS, Espinosa MA \& Vitullo AD 2006 Naturally suppressed apoptosis prevents follicular atresia and oocyte reserve decline in the adult ovary of Lagostomus maximus (Rodentia, Caviomorpha). Reproduction 132 301-308. (doi:10.1530/rep.1.01054)

Jensen FC, Willis MA, Leopardo NP, Espinosa MB \& Vitullo AD 2008 The ovary of the gestating South American plain vizcacha (Lagostomus maximus): supressed apoptosis and corpora lutea persistence. Biology of Reproduction 79 240-246. (doi:10.1095/biolreprod.107.065326)

Kim MR \& Tilly JL 2004 Current concepts in Bcl-2 family member regulation of female germ cell development and survival. Biochemica et Biophysica Acta 1644 205-210. (doi:10.1016/j.bbamcr.2003.10.012)

Kirkin V, Joos S \& Zornis M 2004 The role of Bcl-2 family members in tumorigenesis. Biochemica et Biophysica Acta 1664 229-249. (doi:10. 1016/j.bbamcr.2003.08.009)

Knudson CM, Tung KSK, Tourtellotte WG, Brown GAJ \& Korsmeyer SJ 1995 Bax-deficient mice with lymphoid hyperplasia and male germ cell death. Science 270 96-99. (doi:10.1126/science.270.5233.96)

Kurilo L 1981 Oogenesis in antenatal development in man. Human Genetics 57 86-92. (doi:10.1007/BF00271175) 
Lasko PF \& Ashburner M 1988 The product of the Drosophila gene vasa is very similar to eukaryotic initiation factor-4A. Nature 335 611-617. (doi:10.1038/335611a0)

Lawson KA, Dunn NR \& Roelen BA 1999 Bmp4 is required for the generation of primordial germ cells in the mouse embryo. Genes and Development 13 424-436. (doi:10.1101/gad.13.4.424)

Matova N \& Cooley L 2001 Comparative aspects of animal oogenesis. Developments in Biologicals 231 291-320. (doi:10.1006/dbio.2000. 0120)

McLaren A 1999 Signaling for germ cells. Genes and Development 13 373-376. (doi:10.1101/gad.13.4.373)

Motta PM, Makabe S \& Nottola SA 1997 The ultrastructure of human reproduction. I. The natural history of the female germ cell: origin migration and differentiation inside the developing ovary. Human Reproduction Update 3 281-295. (doi:10.1093/humupd/3.3.281)

Mossman HW \& Duke KL (Eds) 1973 Comparative Morphology of the Mammalian Ovary. Madison: University of Wisconsin Press.

Pepling ME, Wilhem JE, ÓHara AL, Gephardt GW \& Spradling AC 2007 Mouse oocytes within germ cell cysts and primordial follicles contain a Balbiani body. PNAS 104 187-192. (doi:10.1073/pnas.0609923104)

Peters H \& McNatty KP 1980 The Ovary: A Correlation of Structure and Function in Mammals, vol 12, pp 34-43. Berkeley: University of California Press.

Ratts VS, Flaws JA, Kolp R, Sorenson CM \& Tilly JL 1995 Ablation of bcl-2 gene expression decreases the numbers of oocytes and primordial follicles established in the post-natal female mouse gonad. Endocrinology 136 3665-3668. (doi:10.1210/en.136.8.3665)

Reed JC $1994 \mathrm{Bcl}-2$ and the regulation of programmed cell death. Journal of Cell Biology 124 1-6. (doi:10.1083/jcb.124.1.1)

Rucker EB III, Dierisseau P, Wagner KU, Garrett L, Wynshaw-Boris A, Flaws JA \& Hennighausen L $2000 \mathrm{Bcl}-\mathrm{x}$ and bax regulate mouse primordial germ cell survival and apoptosis during embryogenesis. Molecular Endocrinology 14 1038-1052. (doi:10.1210/me.14.7.1038)

Tilly JL 1996a Apoptosis and ovarian function. Reviews of Reproduction 1 162-172. (doi:10.1530/ror.0.0010162)

Tilly JL $1996 b$ The molecular basis of ovarian cell death during germ cell attrition, follicular atresia, and luteolysis. Frontiers in Bioscience 1 d1-11.
Tilly JL 2001 Commuting the death sentence: how oocytes strive to survive. Nature Reviews. Molecular Cell Biology 2 838-848. (doi:10.1038/ 35099086)

Tilly JL, Tilly KI, Kenton ML \& Johnson AL 1995 Expression of members of the bcl-2 gene family in the immature rat ovary: equine chorionic gonadotropin-mediated inhibition of apoptosis is associated with decreased bax and constitutive bcl-2 and bcl-2 long messenger ribonucleic acid levels. Endocrinology 136 232-241. (doi:10.1210/en. 136.1.232)

Tilly JL, Tillly KI \& Perez GI 1997 The genes of cell death and cellular susceptibility to apoptosis in the ovary: a hypothesis. Cell Death and Differentiation 4 180-187. (doi:10.1038/sj.cdd.4400238)

Uma J, Muraly P, Verma-Kumar S \& Medhamurthy R 2003 Determination of onset of apoptosis in granulose cells of the preovulatory follicle in the bonnet monkey (Macaca radiata): correlation with miotgen-activated protein kinase activities. Biology of Reproduction 69 1379-1387. (doi:10.1095/biolreprod.103.017897)

Van Nassaw L, Tao L \& Harrison F 1999 Distribution of apoptosis-related proteins in the quail ovary during folliculogenesis: BCL-2, BAX and CPP32. Acta Histochemica 101 103-112.

Vaskivuo TE, Anttonen M, Herva R, Billig H, Dorland M, te Velde ER, Stenbäck F, Heikinheimo M \& Tapanainen JS 2001 Survival of human ovarian follicles from fetal to adult life: apoptosis, apoptosis-related proteins, and transcription factor GATA-4. Journal of Clinical Endocrinology and Metabolism 86 3421-3429. (doi:10.1210/jc.86.7.3421)

Weir BJ 1970 The management and breeding of some more hystricomorph rodents. Lab Animal 4 83-97. (doi:10.1258/002367770781036562)

Weir BJ 1971a The reproductive organs of the female plains viscacha, Lagostomus maximus. Journal of Reproduction and Fertility 25 365-373. (doi:10.1530/jrf.0.0250365)

Weir BJ $1971 b$ The reproductive physiology of the plains viscacha, Lagostomus maximus. Journal of Reproduction and Fertility 25 355-363. (doi:10.1530/jrf.0.0250355)

Received 15 November 2010

First decision 23 December 2010

Accepted 21 February 2011 